\title{
EFFECT OF PARTIAL OR TOTAL SUBSTITUTION OF OAT HAY BY ROSEMARY (ROSMARINUS OFFICINALIS L.) RESIDUES ON GROWTH, DIGESTIBILITY AND NITROGEN RETENTION IN GROWING QUEUE FINE DE L'OUEST LAMBS
}

\author{
Yagoubi Yathreb $^{1,2^{*}}$, Mahouachi Mokhtar ${ }^{3}$, Mekki Ilyes ${ }^{1}$, Smeti Samir $^{1}$, Hajji Hadhami ${ }^{1}$, Atti Naziha ${ }^{1}$ \\ ${ }^{1}$ University of Carthage, INRA-Tunisia, Laboratoire de Productions Animales et Fourragères, \\ rue Hédi Karray, 2049 Ariana, Tunisia \\ ${ }^{2}$ University of Carthage, INAT, 43 avenue Charles Nicole, Tunis, Tunisia \\ ${ }^{3}$ University of Jendouba, ESAK, Le Kef, Tunisia \\ yagoubiyathreb@hotmail.fr
}

\begin{abstract}
The rosemary essential oil production leads after distillation to considerable amounts of residues that can be valued in animal nutrition to solve the food gap in different areas. For that, a trial was conducted to evaluate the effects of partial or total replacement of oat hay by distilled rosemary residues (RR) on lamb's growth, digestibility and nitrogen balance. The experiment was carried on 28 Queue Fine de l'Ouest (QFO) male lambs (4 months old) with an average body weight (BW) of $15.2+0.16 \mathrm{~kg}$, divided into 4 homogeneous groups (C, RR30, RR70 and RR100) according to their initial BW. All lambs were fed $500 \mathrm{~g}$ of concentrate and different amounts of hay and RR according to different substitution rates of $0,30,70$ and $100 \%$ respectively for C, RR30, RR70 and RR100. The average of total dry matter intake was $884 \mathrm{vs.} 902 \mathrm{~g} / \mathrm{lamb} /$ day for $\mathrm{C}$ and the experimental groups, respectively. The final BW of lambs receiving RR was numerically higher for RR30 and RR70 than C and RR100 but without significant difference. Consequently, the average daily gain was similar among groups. The digestibility of dry matter and organic matter were significantly higher for $\mathrm{C}$ compared to experimental ones $(\mathrm{p}<0.05)$. However, the digestibility of crude protein was higher for C, RR30 and RR70 than that of RR100 group. The urinary and fecal nitrogen losses were unaffected by the diets. However, the nitrogen intake was improved for RR30 and RR70 than C and RR100. The nitrogen balance was positive for all groups. It was significantly higher for C, RR30 and RR70 than RR100 (6.1, 6.9 and 6.4 vs. 2.9, respectively). It was concluded that the oat hay substitution by RR did not alter the growth performance or the digestion but enhanced the nitrogen utilization of QFO lambs until the substitution rate of $70 \%$.
\end{abstract}

Key words: distilled rosemary residues; growth; digestibility; nitrogen balance; lamb

\section{ВЛИЈАНИЕ НА ДЕЛУМНА ИЛИ ЦЕЛОСНА ЗАМЕНА НА ОВЕСНОТО СЕНО CO ОСТАТОЦИ ОД РУЗМАРИН (ROSMARINUS OFFICINALIS L.) ВРЗ ПРИРАСТОТ, СВАРЛИВОСТА И РЕТЕНЦИЈАТА НА АЗОТ КАЈ QFО ЈАГНИЫА ВО РАСТЕЖ}

Производството на есенцијално масло од рузмарин доведува до создавање значителни количини остатоци кои можат да бидат корисни во исхраната на животните за да се реши недостигот од храна. Затоа беше спроведено испитување за да се оценат ефектите од делумна или целосна замена на овесното сено со дестилирани остатоци од рузмарин (RR) врз прирастот на јагнињата, сварливоста и азотниот баланс. Експериментот беше спроведен на 28 машки јагниња Queue Fine de l'Ouest (QFO) (4 месеци стари) со просечна телесна тежина (BW) од 15,2+0,16 kg, поделени на 4 хомогени групи (C, RR30, RR70 и RR100) според нивната почетна BW. Сите јагниња беа хранети со $500 \mathrm{~g}$ концентрат и различни количини сено и RR според различни стапки на замена од 0, 30, 70 и $100 \%$, соодветно за C, RR30, RR70 и RR100. Просекот од вкупниот внес на сува материја (DM) изнесувал 884 наспроти $902 \mathrm{~g} /$ јагне / ден за C и експерименталните групи, соодветно. Конечната телесна тежина (BW) на јагнињата што примале RR беше нумерички повисока кај RR30 и RR70 од C и RR100, но без значајна разлика. Како резултат на тоа, просечниот дневен прираст (ADG) кај групите бил сличен. Сварливоста на сувата материја (DM) и органската материја (OM) беше значително повисока кај групата $\mathrm{C}$ во споредба со експерименталните групи (p < 0,05). Меѓутоа, сварливоста на суров протеин $(\mathrm{CP})$ беше повисока кај C, RR30 и RR70 отколку кај групата RR100. Загубите на уринарниот и фекалниот азот со исхраната не беа променети. Внесот на азот беше подобар кај RR30 и RR70 отколку кај C и RR100. Балансот на азот беше позитивен кај 
сите групи. Тој беше значително повисок кај C, RR30 и RR70 отколку кај RR100 (6.1, 6.9 и 6.4 наспроти 2.9, соодветно). Беше заклучено дека замената на овесно сено со RR не ги променила перформансите на прирастот ниту дигестијата, туку го подобрила искористувањето на азотот кај QFO јагнињата до стапката од 70\% од супституцијата.

Клучни зборови: дестилирани остатоци од рузмарин; раст; сварливост; баланс на азот; јагне

\section{INTRODUCTION}

Sheep feeding in Tunisia is often based on natural vegetation of rangelands and stubble with small supplementation by concentrate. However, these natural resources fluctuate considerably according to climatic changes especially severe drought which limit the availability of feed (Majdoub-Mathlouthi et al., 2013). Consequently, the extensive production system became inefficient in feeding livestock which lead to the use intensive production system for fattening by different diets rich in energy. However, the continuously increasing concentrate prices worsened the situation. Moreover, the development and research activities in the small ruminant sector, particularly for meat sheep, aim to improve feed efficiency as well as reduce feed costs, which account for more than two thirds of meat production cost. These actions concern mainly the possibility of introducing unconventional by-products as a substitute for commonly used roughages.

Many works have evaluated two types of alternative resources as shrubs and agro-industrial byproducts (Ben Salem et al., 2002; Molina-Alcaide and Yànez-Ruiz, 2008; Naserian et al., 2016), however, the distillation by-products as roughages were not mainly studied. Actually, the distillation of aromatic plants is an agro-industrial activity which is becoming increasingly important to extract essential oils. In fact, rosemary is the most widespread plant in the Mediterranean area especially in Tunisia where it occupied 346000 ha. It is used in the distillation industry to produce essential oils (EO) which then, generated abundant amounts of residues in form of distillated leaves (5460 T/ year; Saadani, 2010). Given that these by-products represent $35 \%$ of the distillation residues (RR), this important quantity could be valued as an alternative resource for small ruminants in case of scarce availability of forages to substitute traditional roughages.

Therefore, we aimed to investigate in the current study; the effects of rosemary distillation residues use to partially or totally substitute oat hay on growth performance, digestibility and nitrogen retention for growing Queue Fine de l'Ouest (QFO) lambs.

\section{MATERIAL AND METHODS}

\subsection{Experimental location}

The experiment was conducted at the experimental farm of the High Agriculture School of Kef (ESAK) which is located in the north-west of Tunisia. The rosemary distillation residues were collected from the North and Center-West of Tunisia which contained a chain of mountains of Rosmarinus officinalis $\mathrm{L}$. and where its traditional distillation is frequently practiced. The climate in these areas is semi-arid; annual precipitation averages is about $500 \mathrm{~mm}$ and the peak rainfall occurs in the period December-March.

\subsection{Experimental feed, animals and diets}

The RR used was obtained from traditional distillation. In fact, the Rosmarinus foliage was harvested fresh in July for distillation to produce essential oil. Then, the RR was transferred to the School farm and was sun-dried for 4-5 days. The dry foliage was conserved until lamb's weaning and experiment beginning in February.

Twenty eight male Queue Fine de l'Ouest (QFO) lambs (4 months old, average body weight (BW) $15.2 \pm 0.16 \mathrm{~kg}$ were used for this study. They were treated against enterotoxaemia, internal and external parasites at the beginning of the trial. Animals were housed in individual pens in a covered and ventilated sheepfold with free access to fresh water. They were divided into 4 homogenous groups according to BW. Animals were allowed an adaptation period of two weeks during which they were fed oat hay and concentrate supplement with gradual withdrawal of the hay and introduction of RR for 3 groups. During the last 4 days of this period, the hay voluntary intake was stabilised around $600 \mathrm{~g}$ of fresh matter. Hence, the basal ration offered to lambs of each group was $600 \mathrm{~g}$ of hay and/or RR. The composition of the different forages was:

$>600 \mathrm{~g}$ of hay $+0 \mathrm{~g}$ RR for the control group (C) $(100 \%$ hay and $0 \%$ RR)

$>400 \mathrm{~g}$ of hay $+200 \mathrm{~g}$ RR for RR30 (70 \% hay and $30 \% \mathrm{RR}$ ) 
$200 \mathrm{~g}$ of hay $+400 \mathrm{~g}$ RR for RR70 (30\% hay and $70 \% \mathrm{RR}$ )

$>0 \mathrm{~g}$ of hay $+600 \mathrm{~g}$ RR for RR100 (0\% hay and $100 \%$ RR)

All lambs were offered $500 \mathrm{~g}$ of concentrate. The experiment lasted 75 days which consisted in a feeding ( $\mathrm{d} 1$ to $\mathrm{d} 60$ ) and a digestibility (d60 to d75) trials. Concentrate was offered once daily at 08:00 h. Oat hay and RR were offered in two equal meals at 09:00 and 16:00 $\mathrm{h}$ in separate troughs.

The quantities of offered and refused feed of all lambs were recorded daily before the morning feeding and some samples were taken twice weekly for subsequent chemical analyses. Throughout the trial, animals were weighed every 14 days just prior to food distribution and average daily gain (ADG) was calculated for each lamb.

\subsection{Nutrient digestibility and nitrogen balance}

After the growth trial, a metabolism trial was conducted with 5 lambs from each mentioned group. They were transferred to individual metabolism cages for faecal and urinary collection to evaluate digestibility and nitrogen balance. They were fed the same diets mentioned above for 5 days after 10 days of adaptation to the cages. The quantity of feed offered and refused, fecal output and urine were daily recorded and sampled for further analyses. Representative samples were used for DM, ash and crude protein (CP) analyses. Urine was collected in a plastic container with $50 \mathrm{ml}$ of $10 \%$ $\mathrm{H}_{2} \mathrm{SO}_{4}$. After weighing, $10 \%$ of the total amount of urine after homogenization was conserved at $-4^{\circ} \mathrm{C}$ to determine the $\mathrm{N}$ content.

\subsection{Laboratory analysis}

Ground samples of hay, RR, concentrate and portions of individual pooled samples of refusals and faeces were analyzed for DM by drying at $75^{\circ} \mathrm{C}$. Ash was determined at $550^{\circ} \mathrm{C}$ for $6 \mathrm{~h}$. Nitrogen content of feed, faeces and urine was determined by the Kjeldahl method $(A O A C, 1990)$. The nitrogen $(\mathrm{N})$ balance was calculated from data of $\mathrm{N}$ intake, faecal $\mathrm{N}$, urinary $\mathrm{N}$ by the following formula: retained $\mathrm{N}=$ $\mathrm{N}$ intake - (faecal $\mathrm{N}+$ Urinary $\mathrm{N})$.

\subsection{Statistical analyses}

Statistical analyses were performed by ANOVA as a completely randomized design. The model included the dietary treatment effects and the experimental error for feed intake, nutrient digestibility, nitrogen retention and growth performances. The level of significance was set at 5\%.

\section{RESULTS}

\subsection{Feed chemical composition, feed intake and lamb's growth performance}

Data of feed chemical composition are given in Table 1. The RR had similar DM and OM contents than oat hay. However, it had higher CP content $(7.3 \%$ vs. $5 \%)$ that hay.

Table 1

Chemical composition of experimental feeds (\%)

\begin{tabular}{cccc}
\hline \hline & Oat hay & Concentrate & Rosemary residues \\
\hline $\mathrm{DM}$ & 86.0 & 92.3 & 84.9 \\
$\mathrm{OM}$ & 93.0 & 86.7 & 92.6 \\
$\mathrm{CP}$ & 5.0 & 11.6 & 7.3 \\
\hline \hline
\end{tabular}

$\mathrm{DM}$ - dry matter; OM - organic matter, $\mathrm{CP}$ - crude protein

Data of feed intake are shown in Table 2. During the growth trial, the intake of the different roughages (oat hay and rosemary residues) increased as the distributed amount increased for all lambs. In addition, all the offered amount of concentrate was consumed by lambs. In fact, the DM and $\mathrm{OM}$ intakes were significantly higher for the control group $(\mathrm{P}<0.05)$. However, the CP intake was higher for RR100 and RR70 than C and RR30.

Table 2

Effects of rosemary distillation residues insertion in QFO lamb's diet on feed intake (g/day)

\begin{tabular}{lllllll}
\hline & $\mathrm{C}$ & RR30 & RR70 & RR100 & SEM & P value \\
\hline DMI & $791 \mathrm{a}$ & $741 \mathrm{~b}$ & $732 \mathrm{~b}$ & $756 \mathrm{~b}$ & 4.32 & 0.0004 \\
OMI & $811 \mathrm{a}$ & $756 \mathrm{~b}$ & $746 \mathrm{~b}$ & $771 \mathrm{~b}$ & 4.37 & 0.0001 \\
$\mathrm{CPI}$ & $67.8 \mathrm{c}$ & $68.7 \mathrm{c}$ & $72.5 \mathrm{~b}$ & $78.6 \mathrm{a}$ & 0.44 & 0.0001 \\
\hline
\end{tabular}

DMI - dry matter intake; OMI - organic matter intake; CPI - crude protein intake; SEM - standard error mean

Data of lamb's growth parameters are shown in Table 3. The initial BW was similar among groups $(\mathrm{P}>0.05)$. Numerically the highest final $\mathrm{BW}$ 
was observed for RR70 group. But statistically, it was similar for all groups without significant differrences. Consequently, ADG did not differ among groups $(\mathrm{P}>0.05)$ but still low for all lambs $(<100$ g/day).

Table 3

Effects of rosemary distillation residues insertion in QFO lamb's diet on growth performance

\begin{tabular}{lcccccc}
\hline \hline & C & RR30 & RR70 & RR100 & SEM & P-value \\
\hline Initial BW (kg) & 14.9 & 15.7 & 15.7 & 14.1 & 1.73 & 0.26 \\
Final BW (kg) & 20.3 & 21.1 & 22.1 & 20.1 & 2.36 & 0.43 \\
ADG (g) & 77.0 & 76.0 & 90.0 & 86.0 & 20.64 & 0.50 \\
\hline \hline $\begin{array}{l}\text { BW - body weight; ADG - average daily gain; SEM - standard error } \\
\text { mean }\end{array}$
\end{tabular}

\subsection{Nutrient digestibility and nitrogen balance}

The DM and OM digestibility were higher for the control group than the experimental ones (Table $4, \mathrm{P}<0.05)$. However, the CP digestibility was significantly higher $(\mathrm{P}<0.05)$ for $\mathrm{C}, \mathrm{R} 30$ and $\mathrm{R} 70$ and the total oat hay substitution by $\mathrm{RR}$ resulted in the lower CP digestibility (39.8\%).

Table 4

Effects of rosemary distillation residues insertion in QFO lamb's diet on digestibility parameters

\begin{tabular}{ccccccc}
\hline & C & RR30 & RR70 & RR100 & SEM & P-value \\
\hline DM digestibility & $72.8^{\mathrm{a}}$ & $67.4^{\mathrm{b}}$ & $68.4^{\mathrm{b}}$ & $68.2^{\mathrm{b}}$ & 3.04 & 0.05 \\
OM digestibility & $74.6^{\mathrm{a}}$ & $69.4^{\mathrm{b}}$ & $70.8^{\mathrm{ab}}$ & $70.4^{\mathrm{b}}$ & 2.85 & 0.05 \\
CP digestibility & $63.4^{\mathrm{a}}$ & $65.6^{\mathrm{a}}$ & $62^{\mathrm{a}}$ & $39.8^{\mathrm{b}}$ & 10.72 & 0.005 \\
\hline
\end{tabular}

DM - dry matter; OM - organic matter; $\mathrm{CP}$ - crude protein; SEM - standard error mean

Data of nitrogen intake, nitrogen losses in feces and urines and nitrogen retention are shown in Table 5 . The oat hay substitution by RR resulted in higher nitrogen intake for RR30 and RR70 than C and RR100. Regarding the fecal nitrogen, it was significantly higher for R30, R70 and R100 groups. However, the excreted nitrogen in urine was similar among groups. Despite its higher CP intake, RR100 had the lower $\mathrm{N}$ intake compared to other groups.
Table 5

Effects of rosemary distillation residues insertion in QFO lamb's diet on nitrogen (N) balance

(g/day)

\begin{tabular}{ccccccc}
\hline \hline & C & RR30 & RR70 & RR100 & SEM & P-value \\
\hline NI & $10.8^{\mathrm{b}}$ & $12.4^{\mathrm{a}}$ & $12.4^{\mathrm{a}}$ & $8.9^{\mathrm{c}}$ & 0.65 & 0.0001 \\
$\mathrm{FN}$ & 3.9 & 5.0 & 5.3 & 5.4 & 0.97 & 0.11 \\
$\mathrm{UN}$ & 0.8 & 0.6 & 0.7 & 0.6 & 0.53 & 0.91 \\
$\mathrm{RN}$ & $6.1^{\mathrm{a}}$ & $6.9^{\mathrm{a}}$ & $6.4^{\mathrm{a}}$ & $2.9^{\mathrm{b}}$ & 1.02 & 0.0001 \\
\hline \hline
\end{tabular}

$\mathrm{NI}$ - nitrogen intake; FN - fecal nitrogen; UN - urinary Nitrogen; $\mathrm{RN}$ - retained nitrogen; SEM - standard error mean

\section{DISCUSSION}

\subsection{Feed chemical composition, feed intake and lamb's growth performance}

Given the similarity in DM and OM contents for RR and oat hay, the RR could substitute the conventional feed (hay) in case of food gap. The CP content of RR in the current study is higher than that found by Moujahed et al. (2013) who reported that rosemary contained $5.8 \%$ of $\mathrm{CP}$.

Results of this study suggest that oat hay can be partially or totally substituted by RR in the daily ration of lambs without adverse effects on intake, but instead, the rate of substitution of 70 and $100 \%$ enhanced the CP intake than the control group. This result can be attributed to the higher crude protein content in the rosemary residues given that the ration of lambs of these groups contained the higher amounts of RR.

The variation of BW was influenced by the nature of distributed feeds. By keeping growth rates similar to the control group, a replacement of 30, 70 and $100 \%$ of oat hay by RR can maintain lambs performances. Despite the weak growth rate of lambs, it was comparable to results of Atti et al. (2002) for lambs of the same breed and having similar BW to those in the current study. However, it was higher than results of Ben Salem et al. (2002) and of Mahouachi and Atti. (2005). These results showed the efficiency of these by-products in lamb's nutrition. In addition, it was reported that the use of citrus byproducts enhanced the growth performances of lambs of different breeds and resulted in similar ADG to those of the present study (Rihani, 1991). Moreover, Jeshari et al. (2016) recorded higher growth rate for calves receiving distillate plants than control. Moreover, no effect of rosemary on growth 
performance was detected also in chiks (Yasar et al., 2011) and in pigs as found Janz et al. (2007) that no substantial effect was observed on growth in treated pigs compared to the control group.

Then, the similar feed intake and the comparable growth rates among groups are in agreement with the results found by Mahouachi et al. (2004) who have concluded that comparable initial body weight minimizes differences in nutrient intake and consequently differences in terms of growth performances for Tunisian breeds.

\subsection{Nutrient digestibility and nitrogen balance}

The DM digestibility for all groups in the current study was higher than results found by Kayouli et al. (1989) who reported that the DM digestibility with hay as roughage was about $47 \%$. Generally, the RR insertion had not affected the OM and CP digestibility until the rate of $70 \%$ of substitution. Our results corroborated with those of Smeti et al. (2015) who reported that the supply by rosemary essential oil or its equivalent in rosemary leaves had not affected the OM and CP digestibility.

The RR introduction in lamb's ration increased the nitrogen intake amounts especially for the rates 30 and $70 \%$. However, the RR intake had not affected the fecal nitrogen in contrary to results of Murphy et al. (1994) and those of Atti et al. (2002) who found that the excrected nitrogen in feces is strongly related to the nitrogen supply amount. In the same context, it was reported that the urinary nitrogen decrease with the low nitrogen supply (Rémond et Journet, 1978 ; Murphy et al, 1994). The nitrogen balance was positive for all groups. In fact, the total oat hay substitution by RR resulted in a low retained nitrogen value, however, RR30 group had the higher value (6.9 g/day) given that had also the higher $\mathrm{CP}$ digestibility value. It can be concluded that a rate of $30 \%$ of RR introduction in the regimen is sufficient to enhance the nitrogen retention for QFO lambs.

\section{CONCLUSION}

The results of the current study indicated that the use of distillate rosemary residues to partially or totally substitute oat hay in Queue Fine de l'Ouest lamb's ration, maintain the growth performance without affecting nutrient digestibility, however, it enhanced the nitrogen retention.
Acknowledgements: The authors gratefully acknowledge the ESAK staff for their collaboration and help in the conduct of this study. They are also indebted to INRA-Tunisia staff for their technical help for chemical analyses.

\section{REFERENCES}

[1] AOAC: Association of Official Analytical Chemists. Official Methods of Analysis, $15^{\text {th }} \mathrm{ed}$. Arlington, VA, USA 1990.

[2] Atti, N., Kayouli, C., Mahouachi, M., Guesmi, A., Doreau, M.: Effect of a drastic and extended under feeding on digestion in Barbarine ewe. Anim. FeedSci. Technol., 100, 1-14 (2002).

[3] Ben Salem, H., Atti, N., Priolo, A., Nefzaoui, A.: Polyethyleneglycol in concentrate or feed blocks to deactivate condensed tannins in Acacia cyanophylla Lindl. Foliage. 1. Effects on intake, digestion and growth by Barbarine lambs. Anim. Sci., 75, 127-135 (2002).

[4] Janz, J. A., Morel, P. C., Wilkinson, B. H. Purchas, R. W.: Preliminary investigation of the effects of low-level dietary inclusion of fragrant essential oils and oleoresins on pig performance and pork quality. Meat. Sci., 75, 350-355 (2007).

[5] Jeshari, M., Riasi, A., Hossein Mahdavi A., Khorvash M., Ahmadi F.: Effect of essential oils and distillation residues blends on growth performance and blood metabolites of Holstein calves weaned gradually or abruptly. Livest. Sci.,185, 117-122 (2016).

[6] Kayouli, C., Djemali, M., Belhadj, M. T. (1989): Situation de la production laitière bovine intensive en Tunisie. Opt. Méd.- SérieSéminaires., 6, 97-100.

[7] Mahouachi, M., Atti, N.: Effects of restricted feeding and re-feeding of Barbarine lambs: intake, growth and non-carcass components. Anim. Sci., 81, 305-312 (2005).

[8] Mahouachi, M., Atti, N., Rouissi, H., Tissaoui, M.: Effets de la substitution du tourteau de soja par l'urée sur les performances de croissance des agneaux de race locale Tunisienne. Rev. Tropicul., 22 (1), 26-31 (2004).

[9] Majdoub-Mathlouthi, L., Saïd, B., Say, A., Kraiem, K.: Effect of concentrate level and slaughter body weight on growth performances carcass traits and meat quality of Barbarine lambs fed oat hay based diet. Meat. Sci., 93, 557-563 (2013).

[10] Molina-Alcaide, E., Yànez-Ruiz, D. R.: Potential use of olive by-products in ruminant feeding. Anim. Feed. Sci. Technol., 147 (1-3), 247-264 (2008).

[11] Moujahed, N., Bouaziz, Y. Khelfa, A.: Effects of essential oils from Rosmarinus officinalis and Thymus capitatus on in vitro rumen fermentation in sheep. In H. Ben Salem, A. López-Francos (Eds.), Feeding and management strategies to improve livestock productivity, welfare and product quality under climate change. Opt. Méd, Série A. Séminaires Méditerranéens, 107, 35-38 (2013).

[12] Murphy, T. A., Loerch, S. C., Smith, F. E.: Effects of feeding high concentrate diets at restricted intake on digestibility and nitrogen metabolism in growing lambs. J. Anim. Sci., 72, 1583-1590 (1994). 
[13] Naserian, A. A., Staples, C. R., Ghaffari, M. H.: Effects of replacing wheat bran by pistachio skins on feed intake, nutrient digestibility, milk yield, milk composition and blood metabolites of dairy Saanen goats. J. Anim. Physiol. Anim. Nutr., 100, 256-263 (2016).

[14] Rémond, B., Journet, M.: Effet du niveau d'apport azoté à des vaches au début de lactation sur la production laitière et l'urilisation d'azote. Ann. Zootech., 27, 139-158 (1978).

[15] Rihani, N.: Valeur alimentaire et utilisation des sousproduits des agrumes en alimentation animale. Opt. Méd., 16, 113-117 (1991).
[16] Saadani, Y.: Direction Générale des Forêts - Tunisie. Les biens et services des forêts Tunisiennes: Etat des lieux. Projet AGOR - Atelier de concertation avec les parties prenantes. ENFI - Maroc, 2010.

[17] Smeti, S., Hajji, H., Bouzid, K., Abdelmoula, J., Munoz, F., Mahouachi, M., Atti, N.: Effects of Rosmarinus officinalis L. as essential oils or in form of leaves supplementation on goat's production and metabolic statute. Trop. Anim. Health. Prod., 47, 451-457 (2015).

[18] Yasar, S., Namik, D., Fatih, G., Gokcimen, A. Selcuk, K.: Effects of inclusion aeriel dried parts of some herbs in broiler diets. J. Anim. Plant Sci., 21, 465-476 (2011). 